\title{
Dlaczego kobiety nie mają swojej historii? Wspomnienia Aleksandry Pitsudskiej i ich rola w budowaniu legendy Józefa Piłsudskiego
}

DOI: 10.19195/2083-7763.7.6

\section{Wstęp}

Celem artykułu jest próba odpowiedzi na pytanie dotyczące kreacji bohatera, jaką napotykamy we wspomnieniach żon sławnych mężów. Przedmiotem refleksji stała się postać Józefa Piłsudskiego, któremu Aleksandra Piłsudska, druga żona Marszałka, poświęciła na kartach swoich wspomnień bardzo wiele miejsca. Wiążą się z tym liczne pytania o rolę kobiet w historii. Czy kobiety pisały o swojej historii, czy raczej same skrywały się za historią kreowaną przez mężczyzn?

\section{Czy kobiety mają własną historię?}

Kobiety uczestniczyły w dziejach w takim samym stopniu, jak mężczyźni, były stale obecne nie tylko w przestrzeni domowej, lecz także w sferze życia publicznego. Wiele czynników decydowało o marginalizowaniu kobiet we wszystkich sferach życia. Edukacja nie sprzyjała emancypowaniu się kobiet, presja społeczna spychała je do tradycyjnych ról żony i matki, ale również z tych pozycji je starały się brać aktywny udział w życiu politycznym i społecznym. Ważnym aspektem w dziejach państwa i narodu polskiego pozostaje historia tej jego części, którą stanowią kobiety. Ich sylwetki były odnotowywane na kartach opracowań historycznych, lecz w bardzo specjalnym, ograniczonym aspekcie. Zabrakło w nich historii kobiet, ich zmagań o równouprawnienie i uobywatelnienie. Historia kobiet znajduje porównanie z historią Żydów, historią chłopów polskich, mieszczan, tych wszystkich, którzy nie stanowili narodu, a o prawa i równości musieli walczyć. 
Historycy polscy w przeważającej części byli konserwatystami, utrwalali stereotypy i lansowali wzorce, które nie sprawdzały się już w drugiej połowie wieku XIX, nie dostrzegali, że otaczające ich realia były odmienne niż historia przez nich kreowana. A przecież kobiety uczestniczyły w życiu publicznym i politycznym, prowadziły salony artystyczne, były pisarkami, działaczkami społecznymi, walczyły w powstaniach narodowych i o równouprawnienie kobiet ${ }^{1}$.

Zapisywanie historii kobiet oparte było także na obowiązującym stereotypie, który uznawany był za ideał - wprowadzał on podział ról na sferę męska i kobiecą. Oznaczało to, że mężczyzna przybierał rolę rycerza osłaniającego kobietę, której przypisana została jedyna możliwa do spełnienia rola damy. Sławomira Walczewska tak charakteryzuje ów kontrakt płci:

Zadaniem mężczyzny-rycerza jest walka, opieka i obrona, zadanie kobiety jest komplementarne - ma ona wspierać go duchowo i zapewniać mu wytchnienie i nagrodę po walce. Zrytualizowany system wymogów jednej płci wobec drugiej, obwarowany przez społeczne i kulturowe sankcje i gratyfikacje, wykształcił się na drodze socjo-kulturowego procesu negocjacji między płciami. Efektem tego procesu jest określona relacja między płciami, pewien kontrakt płci. W kulturze polskiej ma on postać kontraktu szlachecko-rycerskiego ${ }^{2}$.

Mimo że wzorzec ten miał swoje korzenie w średniowieczu, pozostawał aktualny w wieku XIX, m.in. lansowany był w literaturze pięknej, pisanej „ku pokrzepieniu serc", a także w Lalce Bolesława Prusa. Model taki odnajdujemy również w relacjach autobiograficznych spisywanych przez kobiety.

Historia pisana w takiej konwencji ustawiała kobiety w roli istot podrzędnych, uległych i poddanych wobec mężczyzn. Dodatkowym elementem podporządkowującym kobiety był etos małżeństwa, w którym mężczyzna spełniał rolę dominującą. Ten obraz uzupełniało macierzyństwo, które stanowić miało powołanie kobiety, a tym samym ograniczało ją do sfery życia domowego.

Tradycja marginalizowania kobiet $\mathrm{w}$ życiu publicznym i szeregowania ich w sferze prywatnej sięga czasów greckiego polis. Ówczesny człowiek oddzielał w swoim życiu sferę prywatną i społeczną. W sferze prywatnej, czyli życiu poza polis, obowiązywały inne zasady postępowania. W sferze społecznej stosowano perswazję, w sferze prywatnej uciekano się często do przemocy. Mężczyzna będący głową rodziny, sprawował nad nią despotyczną władzę ${ }^{3}$. H. Arendt pisze:

wolność sytuuje się wyłącznie w dziedzinie publicznej, że konieczność jest przede wszystkim zjawiskiem przedpolitycznym, cechą charakterystyczną prywatnej organizacji gospodarstwa domowego, i że siła i przemoc w tej sferze są usprawiedliwione, ponieważ są to jedyne środki

${ }^{1}$ M. Sikorska-Kowalska, Nieobecność kobiet w historii na przykładzie wybranych syntez dziejów Polski drugiej połowy XIX w. i początku wieku XX, [w:] Łódź, Polska i Europa Środkowo-Wschodnia w podręcznikach do nauczania historii, red. Z. Anusik et al., Łódź 2013, s. 97-98.

2 S. Walczewska, Damy, rycerze i feministki. Kobiecy dyskurs emancypacyjny w Polsce, Kraków 2000, s. 93-94.

${ }^{3}$ H. Arendt, Kondycja ludzka, przeł. A. Łagodzka, Warszawa 2010, s. 43-46. 
pozwalające zapanować nad koniecznością - na przykład przez rządzenie niewolnikami — i stać się wolnym ${ }^{4}$.

Człowiekiem wolnym i równym mógł być jedynie mężczyzna, on bowiem wychodził w sferę życia publicznego, gdzie wszyscy byli równi. W domu nie było równości ani wolności, wolny był tylko ten, kto nie podlegał życiowym koniecznościom, rządził i wydawał rozkazy ${ }^{5}$. Greckie zasady funkcjonowania społeczeństwa zaciążyły na historii kobiet, których los porównywany był z niewolniczym. Polis utrwaliło myślenie o kobietach jako nieważnym, ukrytym elemencie życia.

Kobiety przez wieki należały do tej ukrytej sfery, która przede wszystkim związana była z cielesnością człowieka. W epoce nowożytnej zaczęto odkrywać bogactwo sfery intymnej i wydobywać jej aktorów z cienia. Kobiety i niewolnicy, główni uczestnicy sfery prywatnej, zaczęli się emancypować6.

Podziały płciowe powstały w wyniku powtarzania codziennych działań i praktyk. Zdaniem J. Butler „[p]łeć jest wytwarzana i dlatego też należy ją rozumieć jako codzienne odtwarzanie różnych gestów ciała, ruchu i póz, które tworzą iluzję trwałego płciowego »ja«"7. Takie rozumienie płci wyjaśnia codzienne procesy jej konstruowania, które determinują kształtowanie się tradycyjnych ról społecznych. Stanowi to jeden $\mathrm{z}$ elementów patriarchalnego społeczeństwa, w którym zasady patriarchalnej rodziny zostały przeniesione do sfery życia publicznego. Patriarchat prywatny dotyczył męskiej dominacji na gruncie domowym, kontroli pojedynczych mężczyzn nad kobietami wewnątrz rodziny. Znalazło to zastosowanie na gruncie publicznym i wpływa na ograniczony dostęp kobiet do rynku pracy, polityki i władzy ${ }^{8}$. S. Walby nazywa to zjawisko „reżimem płci”, który zastosowany został do opisania sytuacji kobiet w okresie powojennym. Reżim płci na początku wieku XX oznaczał przygotowywanie kobiet do pełnienia obowiązków matki i żony, co miało w zasadniczy sposób ograniczyć ich udział w sferze życia publicznego 9 . Wojna spowodowała, że kobiety, które w niej uczestniczyły weszły w obszar życia politycznego. Przyznanie kobietom w Polsce w 1918 r. praw wyborczych otwierało drogę do uczestnictwa w sferze życia publicznego, ale jak podkreślają historycy, był to okres, w którym kobiety uzyskały „równe prawa i nierówne szanse”. Z takiej perspektywy odnoszono się do historii kobiet, która zdominowana była przez historię polityczną. Jak zauważyła Anna Żarnowska:

słabo zaawansowane są także studia nad zróżnicowaniem społecznym zależnym od płci, nad nierównością statusu społecznego mężczyzn i kobiet w Polsce lat międzywojennych - a w szcze-

4 Ibidem, s. 50-51.

${ }^{5}$ Ibidem, s. 52.

6 Ibidem, s. 93-94.

7 J. Butler, Gender Trouble. Feminism and the Subversion of Identity, London 1990, s. 140, za: H. Bradley, Płeć, przeł. E. Chomicka, Warszawa 2008, s. 93.

${ }^{8}$ H. Bradley, op. cit., s. 61.

9 S. Walby, Gender Transormations, London 1997, za: H. Bradley, op. cit., s. 61-62. 
gólności - nad przemianami pozycji kobiet w ramach ówczesnego społeczeństwa i państwa, $\mathrm{z}$ uwzględnieniem kulturowego wymiaru tych zjawisk ${ }^{10}$.

\section{Pamiętniki i wspomnienia w badaniach historii kobiet}

Badanie materiałów biograficznych kobiet wpisuje się w szeroki kontekst kulturowy, służy przede wszystkim odzyskiwaniu, odtwarzaniu historii kobiet i społecznej pamięci o kobietach. Stanowi nie tylko kolekcjonowanie postaci, lecz ukazuje sylwetki kobiet $\mathrm{w}$ różnych kontekstach, wpisuje się w historię narodową, polityczną i społeczną, historię życia codziennego.

W kobiecych relacjach uwzględniona zostaje ponadto perspektywa osobista, która, zdaniem antropologów, rozszerza i pogłębia refleksję o człowieku i otaczającej go rzeczywistości. Perspektywa osobista ukazuje człowieka poszukującego siebie, ale także człowieka w relacji z innym. Stwarza to możliwość badania kobiecej perspektywy, co nie jest jednoznaczne ze światopoglądową oceną rzeczywistości. Daje możliwość ukazania kobiety w historii, społeczeństwie, rodzinie. Dzięki badaniom uwzględniającym osobistą perspektywę mamy możliwość ukazania kobiecego myślenia o sobie i otaczającym ją świecie.

Autobiografie kobiet stanowią ważny wkład do historii, przyczynić się mają do przywracania historii kobiet. Ważnym pytaniem jest, czy istotnie pamiętniki kobiet taką rolę spełniają? Obecnie część postmodernistycznych krytyczek literackich wątpi w siłę tkwiącą w kobiecych autobiografiach: Kobiecy los? Owszem, ale w ramie patriarchatu, wewnątrz jego języka. To, co kobiece, to raczej szczególne miejsca ekspozycji braku, implikowana przez tekst nieciągłość egzystencji, której nie zaradzi hipoteza kobiecej semiotyki objawionej w narracji prywatnej ${ }^{11}$.

I. Iwasiów uważa, że tym samym feministyczna krytyka literacka znalazła się w ślepym zaułku, zataczając koło od podkreślania nieobecności kobiecych autobiografii w androcentrycznym kanonie do konstatacji o niemożności badania nieistniejącej/niewyrażalnej kobiecej podmiotowości ${ }^{12}$.

Feministki drugiej fali, realizujące hasło „prywatne jest polityczne”, uważają, że historia kobiet ma nie być sztucznie wyodrębnionym tworem, ale częścią składową historii ogólnej. Historia kobiet nie jest jednak tym samym co historia mężczyzn, a wydarzenia dziejowe inaczej wpływają na obie płcie $^{13}$.

10 A. Żarnowska, Wprowadzenie, [w:] Równe prawa i nierówne szanse. Kobiety w Polsce międzywojennej, red. A. Żarnowska, A. Szwarc, Warszawa 2000, s. 5.

11 I. Iwasiów, Feminizm 1989-2004, zyskana czy stracona dekada?, http://nowepismo.pl/content/ view/140/89, za: A. Nikliborc, Nieodkryte historie życia polskich kobiet. Teoretyczne i metodologiczne znaczenie kobiecych biografii dla gender studies, [w:] Kalejdoskop genderowy. W drodze do poznania płci społeczno-kulturowej w Polsce, red. K. Slany, B. Kowalska, M. Ślusarczyk, Kraków 2011, s. 80.

12 Ibidem.

13 Ibidem, s. 82. 


\section{Kobieta bohaterem?}

Historycy stawiają również pytanie, czy kobieta może być bohaterem. Uwzględniając pozycję kobiet w rodzinie i społeczeństwie, trudno to sobie wyobrazić. Dodatkowy problem stanowi umiejscowienie kobiet w panteonie bohaterów. Definicje bohatera narodowego wskazują, że bohater to wzór osobowy, reprezentant wspólnoty narodowej, która dokonała takiego wyboru i się z nim identyfikowała. Bohater narodowy w pełni reprezentował wartości narodowe ${ }^{14}$. M. Micińska dostrzegła w polskiej tradycji bogaty wachlarz postaw i wizerunków bohaterów narodowych. Bohaterem narodowym mógł zostać wieszcz, poeta, prorok, „Król Duch”, który czerpiąc z cierpień narodowych, stać się miał wskrzesicielem narodu ${ }^{15}$. Najchętniej jednak czczono wodzów, odważnych wojskowych zasłużonych na polu bitwy, bohaterów jednoczących swoją postawą naród ${ }^{16}$. Jak podkreśla autorka monografii o bohaterach narodowych, „[w] Polsce najwyższą sankcję boską i ludzką mieli wodzowie prowadzący wojska do klęski i tłumaczący tę klęskę poeci" ${ }^{17}$. W tradycji romantycznej wśród bohaterskich cech na plan pierwszy wysuwają się geniusz, odwaga; bohater to heros i buntownik ${ }^{18}$. W panteonie bohaterów narodowych znajdujemy także ludzi zasłużonych dla kultury i nauki, wybitnych polityków ${ }^{19}$. Bohater to także człowiek wcielający w życie wartości społeczne ${ }^{20}$. Bohater to osoba, która podjęła ryzyko i miała odwagę zmagać się z przeciwnościami losu. Bohatera charakteryzuje heroizm, patriotyzm, odwaga duchowa i fizyczna, wytrzymałość.

Jerzy Topolski, kategoryzując bohaterów, zauważył, że kobiety-bohaterki pojawiają się wśród bohaterów zaliczanych do „swego rodzaju moralnego panteonu ludzkości”. Są to kobiety święte, a także takie, które potrafily bezinteresownie się poświęcić, jak Florence Nightingale czy matka Teresa z Kalkuty ${ }^{21}$.

14 J. Kolbuszewska, Bohaterowie narodowi w twórczości Tadeusza Korzona. Uwagi na marginesie „Doli i niedoli Jana Sobieskiego 1629-1674", [w:] Historia - Mentalność - Tożsamość. Miejsce i rola historii oraz historyków w życiu narodu polskiego i ukraińskiego w XIX i XX wieku, red. J. Pisulińska, P. Sierżęga, L. Zaszkilniak, Rzeszów 2008, s. 232-233.

15 M. Micińska, Między Królem Duchem a mieszczaninem. Obraz bohatera narodowego w piśmiennictwie polskim przełomu XIX i XX w. (1890-1914), Wrocław 1995, s. 125.

${ }^{16}$ K. Śreniowska, Kościuszko bohater narodowy. Opinie współczesnych i potomnych 1794-1946, Warszawa 1973, s. 9-11; J. Maternicki, Świadomość historyczna jako przedmiot badań historycznych, [w:] Świadomość historyczna jako przedmiot badań historycznych, socjologicznych i historyczno-dydaktycznych, red. J. Maternicki, Warszawa 1985, s. 31-32.

17 M. Micińska, op. cit., s. 272.

18 M. Janion, M. Żmigrodzka, Romantyzm i historia, Warszawa 1978, s. 185-190.

19 B. Szacka, Społeczna pamięć polskiej przeszłości narodowej w latach 1965-1988, [w:] B. Szacka, A. Sawisz, Studia nad świadomością historyczną, t. 3, Warszawa 1990, s. 18-24.

20 S. Czarnowski, Kult bohaterów i jego społeczne podłoże. Święty Patryk bohater narodowy Irlandii, Dzieła, t. 4, Warszawa 1956, s. 17-18.

21 J. Topolski, Jak się pisze i rozumie historię. Tajemnice narracji historycznej, Poznań 2008, s. 264. 
Wśród nazw charakteryzujących bohatera pojawia się też określenie „bohater zapomniany", bohater bez sławy, którego czyny pozostały w cieniu wielkich wydarzeńn $^{22}$. Charakteryzując bohaterstwo kobiet w powstaniu styczniowym, Maria Bruchnalska nazwała uczestniczki zrywu z 1863 r. „cichymi bohaterkami”23. Uczestnictwo kobiet w historii plasuje się właśnie w kategorii bohaterów drugiego planu. Kobiety, które mogły ubiegać się o miano bohaterek narodowych, znalazły się w cieniu męskiego bohaterstwa. Świadomie zajęły pozycje wspomagające mężczyzn w ich działaniach politycznych i militarnych.

Analiza Wspomnień Aleksandry Piłsudskiej wydaje się potwierdzać tę tezę.

\section{Rys biograficzny}

Aleksandra Szczerbińska (1882-1963) była drugą żoną Józefa Piłsudskiego. Urodziła się w Suwałkach w zubożałej rodzinie szlacheckiej. Po śmierci rodziców wychowywana była przez babkę Karolinę z Truskolaskich Zahorską, która miała wielki wpływ na rozwój intelektualny i emocjonalny przyszłej żony Marszałka Piłsudskiego. Silny charakter i stanowczość Zahorskiej kształtowały patriotyczną postawę Szczerbińskiej. Babka miała ponadto decydujący głos w sprawie edukacji wnuczki. Dzięki jej decyzji Aleksandra ukończyła najpierw gimnazjum w Suwałkach, a następnie studiowała na kursach handlowych w Warszawie ${ }^{24}$. Surowe dzieciństwo i patriotyczna atmosfera domowa leżały u podstaw życiowych wyborów Aleksandry Piłsudskiej. Po wyjeździe do Warszawy nie tylko zajmowała się nauką, lecz także rozpoczęła działalność polityczną. Wstąpiła do PPS w 1904 roku i pracowała w Organizacji Bojowej. Nawiązywała do rodzinnej tradycji walki o niepodległość, do tradycji powstania styczniowego. Przystąpienie do PPS oznaczało dla Aleksandry Szczerbińskiej również niezwykle ważne przemiany w życiu osobistym. W 1906 roku poznała Józefa Piłsudskiego i została jego partnerką, choć do śmierci jego pierwszej żony, Marii Juszkiewiczowej, ich związek nie był zalegalizowany ${ }^{25}$.

Zarys biografii A. Piłsudskiej wskazuje na dylematy kobiet aktywnych przełomu XIX i XX wieku. Wybrała ona zdecydowanie walkę o niepodległość, nie angażując się w walkę o równość płci. Było to jedno z kluczowych zagadnień polskiego ruchu feministycznego, którego liderki zdawały sobie sprawę z tego, że ich głos nie będzie słyszany, dopóki Polska nie odzyska niepodległości ${ }^{26}$.

22 E. Durschmied, Bohaterowie bez sławy, Warszawa 2003, s. 2-9.

23 M. Bruchnalska, Ciche bohaterki. Udziat kobiet $w$ powstaniu styczniowym, t. 1, Miejsce Piastowe 1933.

24 A. Garlicki, Aleksandra Piłsudska, [hasło w:] Polski Słownik Biograficzny, t. XXVI, Wrocław 1981 s. 303-304.

${ }^{25}$ Ibidem.

26 A. Siwik, Kobieta w historii Polski, [w:] Kalejdoskop genderowy..., s. 28. 
Właściwością ruchu kobiecego w Polsce jest wybitnie społeczny jego kierunek. Kobiety innych krajów w dążeniach swoich emancypacyjnych mają głównie na celu wyzwolenie się spod przewagi męskiej, wywalczenie równych z mężczyzną praw. Nasze kobiety dobijają się przede wszystkim o udział w życiu obywatelskim i to bez upominania się o prawa, byleby wolno im było spełniać obywatelskie obowiązki, a więc współdziałać w pracy podejmowanej dla społecznego dobra $[\ldots]^{27}$

pisała Maria Turzyma na łamach krakowskiego „Nowego słowa”. Piłsudska ponadto podzielała romantyczne wizje męża, wychowana w patriotycznej rodzinie, etosie powstań narodowych, była „wiecznym, nieubłaganym i nieuleczalnym spiskowcem"28. Walka o niepodległość była najważniejszym celem i ważnym punktem porozumienia $\mathrm{z}$ J. Piłsudskim.

Aktywność polityczna i działalność bojowa A. Szczerbińskiej zakończyły się wraz z I wojną światową. Jako partnerka, a następnie żona J. Piłsudskiego, angażowała się w prace filantropijne oraz zajmowała wychowaniem córek. Podkreślała jednak niezależność swoich poglądów i wielokrotnie w swoich wypowiedziach utożsamiała się z feministkami.

\section{Cechy kobiecej memuarystyki}

Ważnym elementem niezależności Piłsudskiej były też spisane przez nią Wspomnienia, w których opisała swój udział w ruchu bojowym i scharakteryzowała poglądy. Te fragmenty stanowią jednak margines jej refleksji nad przeszłością. Wspomnienia Aleksandry Piłsudskiej są przede wszystkim zapisem życia Józefa Piłsudskiego oraz streszczeniem jego poglądów. Ukazują nam kobietę ukrytą za cudzą biografią, biografią wybitnego męża, z czcią opisującą jego dokonania i podzielającą jego poglądy. A. Piłsudska jawi się jako postać skromna, dyskretna w opisywaniu życia rodzinnego i zdrad męża, pozbawiona sfery intymności, oszczędnie opisująca sferę macierzyństwa. Jednocześnie poszukująca równości, partnerstwa i przyjaźni w małżeństwie z Józefem Piłsudskim.

Pamiętnik A. Piłsudskiej nie stanowi w tej materii wyjątku. Pamiętniki kobiet zamężnych pisane były często z perspektywy męża. Żony wybitnych postaci prześcigały się w opisywaniu wielkości i talentu oraz oddania i miłości (np. J. Broniewska), jakimi darzyły swoich partnerów. Dotyczyło to również pamiętników pisanych przez kobiety, które deklarowały ściśle prywatny ich charakter. W pamiętniku H.A. Geyer, żony łódzkiego fabrykanta, odnajdujemy opis zmagań pracowitego i ukochanego męża w budowaniu rodzinnej fortuny.

Zamężne kobiety świadomie ukrywały się za biografiami mężów, uważając, że to mężczyźni odgrywali większą rolę niż one w polityce, gospodarce, w czasie wojny, etc. Aleksandra Piłsudska funkcjonowała w orbicie wielkiej polityki,

\footnotetext{
27 M. Turzyma, Dobra i zła wola, „Nowe Słowo” 1902, nr 4.

28 M. Janion, Kobiety i duch inności, Warszawa 2006, s. 98.
} 
związana z najważniejszym politykiem swoich czasów, dzieliła swoje życie na sferę publiczną i prywatną. Obie te sfery nieustannie się przenikały i wypełniały.

Miało to także wpływ na budowanie relacji małżeńskich. Wspomnienia A. Piłsudskiej ukazują nam niezależną z pozoru kobietę, funkcjonującą $\mathrm{w}$ związku, który zdefiniować możemy, jako „relacja władzy”. Pozycja i autorytet wybitnego męża znalazły odbicie na kartach pamiętnika. Piłsudska pozostała w cieniu, przyłączyła się do głosów budujących legendę męża.

Kobieta podporządkowana w małżeństwie wpisywała się w typowy model relacji rodzinnych i społecznych. Małżeństwo podporządkowane „korzyściom obywatelskim" skupiało się na zapewnieniu państwu i rodzinie potomstwa ${ }^{29}$. Żona nie była pozbawiona praw w małżeństwie, ale jak zauważył M. Foucault:

[j]ednak małżeństwo wymagało szczególnego stylu zachowań przede wszystkim dlatego, że mąż był głową rodu, poważnym obywatelem lub kimś, kto zamierza sprawować nad innymi polityczną i moralną zarazem władzę; toteż w owej sztuce życia w małżeństwie chodziło o panowanie nad sobą, które miało kształtować zachowanie roztropnego, umiarkowanego i sprawiedliwego męża ${ }^{30}$.

Stereotypowe zasady funkcjonowania małżeństwa obowiązywały w relacjach Piłsudskich. Małżeństwo podporządkowane było sprawom państwowym, a pełnię władzy sprawował mąż.

Badanie Wspomnień A. Piłsudskiej wpisuje się nie tylko w kontekst badań feministycznych, lecz także w badanie mitów i stereotypów. Legenda Józefa Piłsudskiego, który traktowany jest jako miejsce pamięci Polaków, została zapisana na kartach pamiętnika jego żony. Historycy uznają, że mity i stereotypy oddają udział ludzi w kulturze, obrazy i opowieści oddają symboliczne jej interpretacje. Badania nad mitotwórczą rolą pamiętnika mogą dać odpowiedź, dlaczego celem spisania Wspomnień przez A. Piłsudską nie było opisanie jej własnej historii.

\section{Wspomnienia. Okoliczności powstania. Układ narracji}

Wspomnienia Aleksandry Piłsudskiej po raz pierwszy zostały wydane w Londynie w 1940 roku w języku angielskim, a następnie rok później w Stanach Zjednoczonych. W 1960 r. dokonano przetłumaczenia ich na język polski i ponownie wydano w Londynie. Później kilkakrotnie wznawiano, aby w 2004 roku wydać je z opracowaniem historycznym. A. Piłsudska spisywała wspomnienia będąc w sile wieku (58 lat), zachowując dobrą pamięć. Wspomnienia spisane zostały pod wpływem burzliwych przeżyć związanych z wybuchem wojny, ucieczką z Polski, obrazem zrujnowanego kraju, tragedią krótkiego trwania niepodległego państwa. Zdając sobie sprawę z dramatyzmu sytuacji, jak również z tego,

${ }^{29}$ M. Foucault, Historia seksualności, przeł. B. Banasiak, T. Komendant, K. Matuszewski, Warszawa 1995, s. 516.

30 Ibidem. 
że w nurcie literatury wspomnieniowej o Piłsudskim zabraknąć może jej relacji, zdecydowała się na ich spisanie. Wydaje się także, że nowe okoliczności polityczne sprzyjały podjęciu pisarskiego wyzwania. Piłsudska, pozostając po śmierci męża w kraju, w Warszawie, nie podjęła na bieżąco spisywania wspomnień, choć okoliczności śmierci Marszałka i pogrzeb były dla niej dojmującym przeżyciem. Zdecydowała się na to bardzo szybko na emigracji w Londynie, zdając sobie sprawę z tego, że jako wdowa po Marszałku ma szansę odegrać ważną rolę polityczną $\mathrm{w}$ środowisku emigracyjnym.

Wspomnienia A. Piłsudskiej nie należą do kategorii „późnej biografii”, spisywanej po latach, często u schyłku życia. Miały zapewne terapeutyczny cel, jaki przypisuje się dokumentom osobistym. Ponadto są ważnym elementem w budowaniu legendy J. Piłsudskiego oraz, w pewnym wymiarze, pokazują doświadczenie kobiecości, jakie miała za sobą żona „ojca narodu”.

Pobieżny przegląd spisu treści daje nam już ogólny obraz zawartości Wspomnień, które zostały podzielone na sześć części. Wspomnienia rozpoczyna opis przeżyć z roku 1939 i są to wyłącznie relacje uciekającej wraz z córkami Piłsudskiej. Część druga, zatytułowana „Moje dzieciństwo i lata młodości”, to także opowieść z życia Aleksandry Szczerbińskiej. Oba rozdziały zajmują 55 stron z 277, które stanowią całość pracy. Te dwa rozdziały spinają klamrą życie Aleksandry Piłsudskiej. W pierwszym opisuje moment, kiedy nie ma już z nią męża, w drugim czas, kiedy jeszcze go nie znała.

Następne cztery rozdziały opisują przede wszystkim osobę Józefa Piłsudskiego, a także wspólne życie Piłsudskich. Rozdział trzeci zatytułowany został „Organizacja bojowa i Józef Piłsudski”. Czwarty — „Wojsko i wojna 1914 r.”, piąty — „W odrodzonej Rzeczypospolitej”, natomiast szósty „O silny ustrój i trwałe rządy”. Podział Wspomnień na rozdziały jasno sygnalizuje, że nie jest to opowieść o Aleksandrze Piłsudskiej i jej zmaganiach życiowych. Jest to historia odradzającego się państwa polskiego i postaci Józefa Piłsudskiego, który odegrał największą rolę w tym dziele.

Dobitnie świadczą o tym podtytuły, np. „Niepodległość i socjalizm - Robotnik - Aresztowania i ucieczka Piłsudskiego" 31 albo „Prace Naczelnika Państwa Zabójstwo Narutowicza - Wycofanie się z życia politycznego"32.

Postać Piłsudskiej przewija się w tej narracji, ale jest ona nierozłącznie powiązana $\mathrm{z}$ mężem. Ciekawym przykładem jest fragment Wspomnień, zatytułowany „Życie rodzinne”. Został on umieszczony w ostatnim rozdziale, po części poświęconej śmierci Piłsudskiego, a przed fragmentem końcowym, który dotyczy uroczystości pogrzebowych. Na dziesięciu stronach Aleksandra Piłsudska postanowiła opisać życie rodzinne. Ta część Wspomnień, jak i większość pozostałych, poświęcona została pamięci Piłsudskiego. Marszałek został bowiem ukazany jako

\footnotetext{
31 A. Piłsudska, Wspomnienia, Warszawa 1989, s. 98-107.

32 Ibidem, s. 197-208.
} 
idealny ojciec, pamiętający o urodzinach córek i żony, spędzający z nimi urlop, interesujący się postępami w nauce. We Wspomnieniach nie odnajdujemy relacji dotyczących więzi, jakie łączyły Piłsudską z córkami. Ona sama uważała się za osobę skrytą i niepotrafiącą okazywać uczuć, i być może ten fakt wpływał na jej relacje z mężem i najbliższymi. Legendę Piłsudskiego jako idealnego męża i ojca Aleksandra zaczęła budować już w roku 1936. Ukazała się wówczas książka Marszałek $w \dot{z} y c i u$ codziennym, która została napisana przez M.J. Wielopolską ${ }^{33}$ pod dyktando Piłsudskiej, o czym informowała na kartach Wspomnień.

We fragmencie zatytułowanym „Życie rodzinne” odnajdujemy jednak głębsze odniesienia do sfery prywatnej. Piłsudska wykorzystała je, aby rozliczyć się z plotkami dotyczącymi romansu Piłsudskiego z Lewicką. Rysując obraz Marszałka jako wzorowego ojca, pisała jednocześnie:

[t]akże potwarz i plotka, rozsiewane z perfidią i wielką umiejętnością nie dawały żyć ani mnie, ani rodzinie męża, ani naszym przyjaciołom. Opowiadano, że się rozwodzi i żeni z młodą osobą i porzuca niekochane dzieci. Rozsiewano pogłoski, że mąż bije dzieci szablą ${ }^{34}$.

Opisy miłości do córek wpisywały się też w nadrzędny cel Wspomnień. Legenda Piłsudskiego uzupełniona została o miłość do dzieci, i to nie tylko własnych:

[t]a miłość do dzieci stanowiła jedną z jego głównych cech. Przejawiała się w niej najlepiej jego miłość do człowieka i do narodu: budował Polskę nie tylko dla swego pokolenia, ale i dla tych, co przyjść miały po nim. A radosny śmiech dzieci był dla niego najcenniejszą zapłatą za trudy i mękę życia ${ }^{35}$.

Przywołane we fragmencie części szóstej Wspomnień życie rodzinne miało jednak znacznie więcej odcieni. Józef Piłsudski poznał Aleksandrę Szczerbińską w maju 1906 roku Miała ona wówczas 24 lata i była młodsza od niego o lat piętnaście. Piętnaście lat minęło także, zanim para ta stanęła na ślubnym kobiercu. 25 października 1921 roku Aleksandra Szczerbińska ${ }^{36}$ została żoną Józefa Piłsudskiego. Dzień zaślubin Naczelnika Państwa z towarzyszką Olą poprzedziło nie tylko wiele ważnych wydarzeń związanych $\mathrm{z}$ odbudową państwa polskiego, ale też wiele przeżyć osobistych obojga. W dniu ślubu małżonkom towarzyszyły dwie córki: czteroletnia Wanda i dwuletnia Jadwiga. Dzień ślubu poprzedziła śmierć pierwszej żony Piłsudskiego Marii, która zmarła w Krakowie w nocy z 16 na 17 sierpnia 1921 roku, mając lat 55, nie dożywszy starości.

Krótki opis piętnastu lat wspólnych zmagań o wspólne życie i o niepodległość państwa oddaje trudy, jakie musiała pokonać Aleksandra Szczerbińska, aby zostać

33 M.J. Wielopolska, Józef Piłsudski w życiu codziennym, Warszawa 1936.

34 A. Piłsudska, op. cit., s. 269.

35 Ibidem, s. 264.

36 S. Chutnik, Feministka Pierwsza Dama II RP, www.feminoteka.pl/muzeum/ [dostęp: 18.04.2014]; A. Garlicki, op. cit. s. 303-304; o związku A. Szczerbińskiej z J. Piłsudskim zob. I. Kienzler, Kobiety w życiu Marszałka Piłsudskiego, Warszawa 2012, s. 105-240; L. Malinowski, Miłości Marszałka Piłsudskiego, Warszawa 1997, s. 70-114. 
żoną Piłsudskiego. Piłsudscy poznali się w czasie rewolucji 1905-1907 roku i ten okres jest dobrze udokumentowany we Wspomnieniach. Był to moment, w którym Szczerbińska wyrasta na samodzielną bohaterkę. Aleksandra Szczerbińska odegrała bardzo ważną rolę w okresie rewolucji 1905 roku oraz w czasie poprzedzającym pierwszą wojnę światową. Na jej barkach spoczywała opieka nad składami broni należącymi do PPS Frakcji Rewolucyjnej. Zajmowała się też jej zakupem, transportowaniem przez granicę, dostarczaniem na miejsce akcji bojowych. Uczestniczyła w manifestacji na Placu Grzybowskim 13 listopada 1904 roku, która była od czasów powstania styczniowego pierwszym zrywem z użyciem broni. Pisała o swoim udziale:

Pamiętam, z jakim zdenerwowaniem spoglądałam w kościele co chwila na zegarek i jak nieznośnie powoli posuwały się wskazówki. [...] Cała uwaga była skierowana na to, co ma się stać. Nareszcie padły słowa „Ite, missa est” i ludzie poczęli wychodzić z kościoła. [...] Nagle na ulicy zabrzmiały wystrzały, Czerwony Sztandar oraz Warszawianka. Prawie jednocześnie doleciał do mych uszu odgłos kopyt końskich. Widocznie kawaleria szarżowała na pochód. Kościół na nowo napełniał się ludźmi. Wtem wielkie odrzwia kościoła $\mathrm{z}$ łoskotem zamknięto. Spojrzałam przez ramię — przy wejściu stała policja. Za chwilę usłyszałam kroki tuż przy sobie, ktoś ukląkł i zobaczyłam znajomą twarz - był to młody doktor, towarzysz z PPS, Zandr. Położył dwa rewolwery obok mnie na ławce i szepnął: „Schowajcie szybko”. Odszedł zanim zdążyłam mu odpowiedzieć. Pozostałam przez chwilę w tej samej pozycji, z głową w dłoniach, nachylona, niby to w rozmodleniu, a w rzeczywistości nie wiedząc, co dalej robić. Spojrzałam z ukosa w stronę drzwi - policja rewidowała każdego przy wyjściu. Nie ma więc nadziei na zabranie broni ze sobą [...] Obok stał ciężki, staroświecki klęcznik. Zasłaniając rewolwery fałdami sukni, wsunęłam je szybko pod klęcznik; było mało prawdopodobne, aby ktoś go kiedykolwiek ruszał. Przy wyjściu zrewidowano mnie; w następnej chwili byłam już na ulicy. Plac Grzybowski był zupełnie pusty; kilkanaście ciał leżało na bruku. [...] Nazajutrz wróciłam do kościoła i zabrałam rewolwery ${ }^{37}$.

Szczerbińska $\mathrm{z}$ wielką odwagą brała udział w innych akcjach bojowych PPS Frakcji Rewolucyjnej. Uczestniczyła w jednej z najważniejszych akcji organizowanych przez J. Piłsudskiego, w tzw. akcji pod Bezdanami, podczas której 26 września 1908 roku bojówka PPS dokonała napadu na pociąg przewożący kasę.

Okres po rewolucji 1905 roku i czas I wojny światowej to moment bardzo złożonych relacji osobistych Aleksandry i Józefa oraz czas pełnego zaangażowania obojga w sprawy niepodległości. Ponadto J. Piłsudski nadal pozostawał w związku małżeńskim i nie zamierzał przeprowadzić rozwodu. Mimo to w czasie wojny relacje między Piłsudskimi zacieśniły się, prowadzili nadal ożywioną korespondencję, pełną serdeczności i gorących wyznań, które Piłsudski pisał do „Drogiej i Kochanej Oleńki”38. Był to również okres, w którym Aleksandra Szczerbińska rozwijała indywidualną działalność bojową.

37 A Piłsudska, op. cit., s. 59.

38 Z. Wójcik, Z listów Józefa Piłsudskiego do Aleksandry Sczerbińskiej, „Tygodnik Powszechny” 1988 , nr 46. 


\section{Wątki feministyczne w narracji Piłsudskiej}

Aleksandra Piłsudska uważała, że wpływ zachodniego ruchu feministycznego odgrywał niebagatelną rolę w kształtowaniu się nie tylko kierunku emancypacyjnego w polskim ruchu kobiecym, lecz także poglądy te znajdowały odbicie wśród polskich socjalistek oraz organizatorek ruchów paramilitarnych.

W roku 1912 nadeszła nareszcie okazja do czynniejszego zaangażowania się w Związku Strzeleckim. Piłsudski przyrzekł bardzo dawno, że gdy tylko uda mu się stworzyć siły zbrojne, nie zapomni i o oddziale kobiecym. Ruch feministyczny rozszerzał się wówczas po całej Europie. W Anglii sufrażystki przykuwały się do krat na ulicach i podpalały zamki, w walce o prawa kobiet. Zyskiwały sympatię we Francji i w innych krajach. Przy powszechnym niemal sprzeciwie jedynie socjalizm przyznawał kobiecie równouprawnienie z mężczyznami ${ }^{39}$.

W Związku Strzeleckim utworzono sekcję kobiecą, na czele jednej z nich stanęła przyszła żona Józefa Piłsudskiego, która przeszła przeszkolenie wojskowe ${ }^{40}$. Sekcja ta była niezbyt liczna - na początku 1912 roku było to 60 kobiet - i zajmowała się pracą wywiadowczo-kurierską już w okresie poprzedzającym wybuch wojny.

Piłsudska często odnosiła się do wątków feministycznych i poglądów w swojej biografii, rzadko jednak wspominała jedno z najważniejszych przedsięwzięć, jakie zrealizowano z jej inicjatywy - były to dwutomowe wspomnienia uczestniczek pierwszej wojny światowej. Publikacja ta była świadectwem feministycznej postawy Piłsudskiej, jej deklaracją ideową i manifestem. Wspomnienia uczestniczek walk o niepodległość z lat 1910-1918 uważa się za pierwsze tego typu wydawnictwo źródłowe w Polsce: Wierna służba. Wspomnienia uczestniczek walk o niepodległość 1910-1915 (Warszawa 1927); Stużba ojczyźnie. Wspomnienia uczestniczek walk o niepodległość 1915-1918 (Warszawa 1929). Książki miały na celu zebranie informacji dotyczących udziału kobiet zaangażowanych w działalność patriotyczną i bojową przed wybuchem I wojny światowej oraz w czasie jej trwania - kobiet, które zmobilizowane były pod komendą Józefa Piłsudskiego. Wydawnictwo miało charakter pionierski, niemający wzorów w literaturze polskiej i obcej. Redaktorki tomu pisały we wstępie tonem pełnym patosu:

Nie jest to historia. Są to osobiste wspomnienia uczestniczek ważnych wypadków dziejowych, ujęte wszakże w ramy ciągłości historycznej. Niechaj ta mała karta w wielkiej księdze walki o życie Narodu będzie świadectwem konkretnego czynu, podejmowanego z radosną wiarą w sprawę i Wodza ${ }^{41}$.

Wszystkie artykuły poświęcone były wspomnieniom na niwie pracy bojowej lub partyjnej.

39 A. Piłsudska, op. cit., s. 125.

40 Ibidem, s. 125-126; uczestniczki zostały przeszkolone w zakresie taktyki wojskowej, sygnalizacji, terenoznawstwa, obsługi broni, obronności miast, geografii militarnej, transportu, materiałów wybuchowych oraz organizacji armii rosyjskiej.

41 Wierna służba. Wspomnienia uczestniczek walk o niepodległość 1910-1915, red. A. Piłsudska et al., Warszawa 1927, s. 7. 
W swojej pracy bojowej zetknęła się już wcześniej w Galicji z feministkami krakowskimi. Do oddziałów kobiecych zgłosiła się Maria Turzyma, redaktorka krakowskiego pisma feministycznego „Nowe Słowo”, która miała wówczas ponad sześćdziesiąt lat. Ze Szczerbińską współpracowały także Dulębianka, Odrzywolska i Szrenclowa. W charakterystyce galicyjskich feministek podkreślała ich zaangażowanie w pracę, gorący patriotyzm i zainteresowanie sprawami wojny $^{42}$. Piłsudska chętnie poruszała w swoich wypowiedziach problematykę kobiecą. Choć sama nie uczestniczyła w pracach ruchu feministycznego, stawiała się w roli jego ambasadorki. We wrześniu 1939 roku, uciekając z objętej wojną Polski, znalazła się wraz z córkami w Sztokholmie: „W Sztokholmie udzieliłam wywiadu dziennikarce szwedzkiej, która nie wiedziała o tym, że w Polsce kobiety mają równe prawa $\mathrm{z}$ mężczyznami i że w sejmie zasiadało kilkanaście kobiet. Poinformowałam ją również o ośmiogodzinnym dniu pracy i ubezpieczeniach społecznych"43.

Problematyka feministyczna pojawiała się także w polemikach $\mathrm{z}$ mężem. Kultywująca osobę Marszałka, Aleksandra nigdy nie sprzeciwiła się jego poglądom ani realizowanej polityce, w tej jednej kwestii wygłaszała odrębne poglądy:

nasze rozmowy były prawie zawsze harmonijne, to jednak różniliśmy się co do jednej kwestii: było nią równouprawnienie kobiet. Piłsudski, zgadzając się z tym, że w wolnej Polsce kobiety winny mieć prawa równe z mężczyznami, utrzymywał, że nie będą one umiały wykorzystać swych praw rozsądnie, gdyż mentalność kobiety z natury jest konserwatywna i łatwo jest na nie wpływać. Ja, zacięta feministka, ogromnie się na to oburzyłam ${ }^{44}$.

\section{Podsumowanie. Życie w cieniu legendy}

W swoich wspomnieniach, mimo wielu trudów, jakie towarzyszyły jej życiu z Piłsudskim, Aleksandra zanotowała:

Dopiero po latach przekonałam się, że przyjaźń jest najlepszym fundamentem miłości. Przez długi czas nie zaznaliśmy nic z tego, co się uważa za podstawę szczęśliwego małżeństwa, nie mieliśmy ani domu, ani spokoju, ani bezpieczeństwa. Zamiast tego - ciągłą pracę, częstą biedę, niebezpieczeństwo i niepewność jutra. Miłość nasza przetrwała to wszystko, i co równie ważne, przeżyła później lata spokoju i zwycięstwa ${ }^{45}$.

Bardzo wiele poświęcenia kosztowało Aleksandrę Szczerbińską życie z Komendantem, Naczelnikiem Państwa, a najwięcej z dyktatorem.

Aleksandra Piłsudska reprezentowała typ kobiety, który imponował Piłsudskiemu. W latach młodości, zaangażowana w działalność spiskowo-bojową, a później społeczną, była kobietą ambitną i odważną. Sama także podkreślała, że zawsze zachowywała

\footnotetext{
42 A. Piłsudska, op. cit., s. 126.

43 Ibidem, s. 32.

44 Ibidem, s. 87.

45 Ibidem, s. 105.
} 
odrębne zdanie. Nie uczestniczyła w życiu politycznym i nie miała na nie wpływu, nie przejawiała też takich ambicji, nie pragnęła nawet odgrywać takiej roli.

Odsuwając się od działalności politycznej, Piłsudska zaraz po odzyskaniu niepodległości stanęła na straży legendy męża. Była to również jej historia. Komentowała i poprawiała książki dotyczące akcji pod Bezdanami oraz biografię Józefa Piłsudskiego. Jej działania pokazują kobietę pragnącą sprawować kontrolę nad historią. Sprzeciwiała się wydaniu książki Akcja bojowa pod Bezdanami ${ }^{46}$, uważając, że nie warto przypominać w roku 1933 angażowania się Piłsudskiego w działalność socjalistyczną i terrorystyczną. Weszła tym samym w osobisty spór z autorem książki Władysławem Pobogiem-Malinowskim - uważała, że książka stawiała w złym świetle dokonania bojowców z PPS ${ }^{47}$. Na łamach Wspomnień bardzo oględnie odniosła się do sprawy publikacji, choć w rzeczywistości była w nią mocno zaangażowana. Spór pogłębił się, gdy ten sam historyk w biografii Marszałka opisał okoliczności zawarcia ślubu z pierwszą żoną - co wymagało zmiany konwersji, bo ślub zawarty został w kościele ewangelickim. Problem miał jednak znacznie bardziej osobiste podłoże. Pobóg-Malinowski opisał w jasnych barwach związek Piłsudskiego z Juszkiewiczową ${ }^{48}$. Piłsudska nie tylko wyraziła swoją krytyczną opinię na temat książek W. Pobóg-Malinowskiego, lecz przystąpiła do ataku na łamach prasy. Ponownie posłużyła się osobą M.J. Wielopolskiej, która pisała $\mathrm{w}$ ostrych słowach $\mathrm{w}$ warszawskim „Kurierze Porannym” o obu pracach $^{49}$.

Stając na straży legendy Piłsudskiego, świadomie nią sterując, Piłsudska zrezygnowała $\mathrm{z}$ napisania własnej historii, podkreślenia własnej roli w polityce. Zaangażowała się w osobiste spory i utarczki, popychana zazdrością, nie wykorzystała funkcji, jaką mogła pełnić. Żony wybitnych polityków okresu międzywojennego miały ambicje polityczne i próbowały odegrać samodzielną rolę. Nie dotyczyło to wyłącznie Eleanor Roosevelt. W Europie Środkowej postać A. Piłsudskiej porównywać można z żoną czechosłowackiego polityka, Charlottą GarrigueMasarykową, albowiem zarówno T. Masaryk, jak i J. Piłsudski zyskali w swoich krajach miano „ojców niepodległości”, „ojców narodu”.

Kobiety nie mają swojej historii, bo zabrakło miejsca na tę historię w męskich narracjach. Ponadto, przyczyniło się do tego podporządkowanie tradycyjnym normom obyczajowym, które sprawiały, iż kobiety były ignorowane w relacjach społecznych i politycznych. Były one też często gorzej wykształcone, a nade wszystko całkowicie oddane mężczyznom, których kariery wspierały.

Ponadto nie mają swojej historii, gdyż nawet jeśli potrafiły myśleć i pisać, to spisały historię mężów, synów i braci. Uznały, że ich wkład do polityki, rozwoju

46 W. Pobóg-Malinowski, Akcja bojowa pod Bezdannami 26 IX 1908, Warszawa 1933.

47 A. Prokopiak-Lewandowska, Władysław Pobóg-Malinowski (1899-1962). Życie i dzieła, Warszawa-Bełchatów 2012, s. 119-123.

48 Ibidem, s. 134-137.

49 Ibidem, 116-118. 
społeczeństwa był tak mały, że nie warto o nim wspominać. Kobiety zawsze uważały, że stanowią tylko siły pomocnicze w powstaniach, wojnach, rewolucjach i w domu. Było to zgodne z męskim stosunkiem do „wojny” kobiet.

Wspomnienia, które spisała na początku lat czterdziestych XX w. w Londynie, są zapisem życia Józefa Piłsudskiego, nie tylko tej części, którą spędzili razem, lecz także tych jego fragmentów, które Józef opowiedział Aleksandrze. Wspomnienia są hołdem złożonym wielkiemu człowiekowi i wspaniałemu mężowi, nie ma w nich słów skargi.

Ze Wspomnień A. Piłsudskiej przebijają fragmenty wielkiej historii kobiet. Historia rewolucji 1905 roku oraz I wojny światowej to w znacznym wymiarze historia działalności politycznej, społecznej i militarnej kobiet. Piłsudska miała tego świadomość i dała temu wyraz w opublikowanej pod jej auspicjami dwutomowej edycji wspomnień uczestniczek walk o niepodległość. Jednocześnie jednak bardzo mało miejsca poświęciła we Wspomnieniach na relacje o innych kobietach, z którymi współpracowała czy przyjaźniła się w czasie swojej działalności w PPS i w czasie I wojny światowej.

Wspomnienia A. Piłsudskiej nie są często i obszernie wykorzystywane przez historyków, gdyż ich z założenia subiektywny charakter daje wyłącznie jednostronną opinię. Stanowią jednak ważny i ciekawy materiał źródłowy do badania historii kobiet i kobiecej biografistyki, mimo że ich głównym celem było napisanie historii wybitnego męża.

\section{Bibliografia}

Arendt H., Kondycja ludzka, przeł. A. Łagodzka, Warszawa 2010.

Bradley H., Pteć, przeł. E. Chomicka, Warszawa 2008.

Bruchnalska M., Ciche bohaterki. Udzial kobiet w powstaniu styczniowym, t. 1, Miejsce Piastowe 1933.

Butler J., Gender Trouble. Feminism and the Subversion of Identity, London 1990.

Durschmied E., Bohaterowie bez sławy, Warszawa 2003.

Foucault M., Historia seksualności, przeł. B. Banasiak, T. Komendant, K. Matuszewski, Warszawa 1995.

Garlicki A., Aleksandra Piłsudska, [hasło w:] Polski Słownik Biograficzny, t. XXVI, Wrocław 1981.

Iwasiów I., Feminizm 1989-2004, zyskana czy stracona dekada?, http://nowepismo.pl/content/view/ $140 / 89$.

Janion M., Kobiety i duch inności, Warszawa 2006.

Janion M., Żmigrodzka M., Romantyzm i historia, Warszawa 1978.

Kolbuszewska J., Bohaterowie narodowi w twórczości Tadeusza Korzona. Uwagi na marginesie „Doli i niedoli Jana Sobieskiego 1629-1674”, [w:] Historia - Mentalność - Tożsamość. Miejsce i rola historii oraz historyków w życiu narodu polskiego i ukraińskiego w XIX i XX wieku, red. J. Pisulińska, P. Sierżęga, L. Zaszkilniak, Rzeszów 2008.

Maternicki J., Świadomość historyczna jako przedmiot badań historycznych, [w:] Świadomość historyczna jako przedmiot badań historycznych, socjologicznych i historyczno-dydaktycznych, red. J. Maternicki, Warszawa 1985. 
Micińska M., Między Królem Duchem a mieszczaninem. Obraz bohatera narodowego w piśmiennictwie polskim przełomu XIX $i$ XX w. (1890-1914), Wrocław 1995.

Nikliborc A., Nieodkryte historie życia polskich kobiet. Teoretyczne i metodologiczne znaczenie kobiecych biografii dla gender studies, [w:] Kalejdoskop genderowy. W drodze do poznania płci społeczno-kulturowej w Polsce, red. K. Slany, B. Kowalska, M. Ślusarczyk, Kraków 2011.

Piłsudska A., Wspomnienia, Warszawa 1989.

Pobóg-Malinowski W., Akcja bojowa pod Bezdannami 26 IX 1908, Warszawa 1933.

Prokopiak-Lewandowska A., Władysław Pobóg-Malinowski (1899-1962). Życie i dzieła, WarszawaBełchatów 1933.

Sikorska-Kowalska M., Nieobecność kobiet w historii na przykładzie wybranych syntez dziejów Polski drugiej połowy XIX w. I początku wieku XX, [w:] Łódź, Polska I Europa Środkowo-Wschodnia $w$ podręczniakach do nauczania historii, red. Z. Anusik et al., Łódź 2013.

Siwik A., Kobieta w historii Polski, [w:] Kalejdoskop genderowy. W drodze do poznania płci społecznokulturowej w Polsce, Kraków 2011.

Szacka B., Społeczna pamięć polskiej przeszłości narodowej w latach 1965-1988, [w:] B. Szacka, A. Sawisz, Studia nad świadomością historyczną, t. 3, Warszawa 1990.

Śreniowska K., Kościuszko bohater narodowy. Opinie współczesnych i potomnych 1794-1946, Warszawa 1973.

Topolski J., Jak się pisze i rozumie historię. Tajemnice narracji historycznej, Poznań 2008.

Turzyma M., Dobra i zła wola, „Nowe Słowo” 1902, nr 4.

Walby S., Gender Transormations, London 1997.

Walczewska S., Damy, rycerze i feministki. Kobiecy dyskurs emancypacyjny w Polsce, Kraków 2000.

Wielopolska M.J., Józef Piłsudski w życiu codziennym, Warszawa 1936.

Wierna służba. Wspomnienia uczestniczek walk o niepodległość 1910-1915, red. A. Piłsudska et al., Warszawa 1927.

Wójcik Z., Z listów Józefa Piłsudskiego do Aleksandry Sczerbińskiej, „Tygodnik Powszechny” 1988, $\mathrm{nr} 46$.

Żarnowska A., Wprowadzenie, [w:] Równe prawa i nierówne szanse. Kobiety w Polsce międzywojennej, red. A. Żarnowska, A. Szwarc, Warszawa 2000.

\section{Why women do not have their history? Memories of Aleksandra Pitsudska and their role in development of a legend of Józef Piłsudski}

\section{Summary}

A research on women biographical sources belongs to the wide cultural context, and is aiming at collecting and recording of the history and social memory of women. It is not a simple collecting of women's figures but shows their picture in several contexts, including national, political, social history as well as history of everyday life.

Memoirs of Aleksandra Piłsudska are first of all a record of life of Józef Piłsudski and a presentation of his ideas. They show a woman hidden behind a biography of her husband, describing with respect his achievements and sharing his beliefs. She appears as a modest woman, discrete in describing family life and husband's betrayals, maternity matters. At the same time she is looking for equality, partnership and friendship with Józef Piłsudski.

In Memoirs we can also find fragments of a great history of women. Histories of revolution of 1905 and the First World War are very important for political, social and military activity of women. 